\title{
LEPIDIUM SATIVUM L. AS TEST-ORGANISM FOR ASSESSMENT OF ENVIRONMENTAL POLLUTION
}

\author{
Danute Marčiulionien $\dot{e}^{I}$ \\ Danguole Montvydien $\dot{e}^{l}$ \\ Vilmante Karlavičien $\dot{e}^{2,3}$ \\ William Hogland ${ }^{3}$ \\ 'Institute of Botany, Lithuania \\ ${ }^{2}$ Vilnius Gediminas Technical University, Lithuania \\ ${ }^{3}$ University of Kalmar, Sweden
}

\begin{abstract}
Polluting substances when released into environment become one of the main factors of environmental pollution since they cause changes to the chemical composition of water, bottom sediments and soil; they also disturb the biological balance and self-cleaning processes of the ecosystem that may lead to unpredictable alterations within the ecosystem. Together with the chemical and physical techniques the methods of bioindication and biotesting are employed in the current research on environmental pollution and its impact on the ecological integrity of ecosystems.
\end{abstract}

The aim of this paper was to determine the sensitivity of a test-organism L. sativum to the toxic impact of different types of samples (liquid or solid: surface water, industrial wastewater, industrial storm water, landfill leachate, lake bottom sediments and sludge from industrial storm water sedimentation tank) from urban environment and chemical substances and to demonstrate the possibilities of application of this plant in both the toxicological investigation and environmental pollution assessment.

The results of conducted investigation have proved that L. sativum is a sufficiently universal, cheap and sensitive biotest for determination of toxicity of different types of samples (storm water, bottom sediments, soil, wastewater from industrial sites, landfill leachate) and included chemical substances. Therefore, it can be successfully applied in the environmental pollution assessment.

\section{KEYWORDS}

Lepidium sativum L.; Toxicity; Environmental pollution; Surface water; Storm water; Landfill leachate; Bottom sediments, Environmental pollution assessment

\section{INTRODUCTION}

Polluting substances when released into environment become one of the main factors of environmental pollution since they cause changes to the chemical composition of water, 
bottom sediments and soil; they also disturb the biological balance and self-cleaning processes of the ecosystem that may lead to unpredictable alterations within the ecosystem.

Most frequently the pollution (or quality) of water, bottom sediments and soil is assessed using physical and chemical methods; however, these methods have some drawbacks, for instance a) they do not reflect the transformation of polluting substances in water, their interaction and bioavailability; b) they do not allow assessing the integrated toxic impact of polluting substances on organisms since environmental pollution usually tends to be multicomponent; c) the concentration of polluting substances present in soil or water does not always indicate the toxic impact of these substances on organisms since the toxicity is defined as a biological feature [1,2]. Together with the chemical and physical techniques the methods of bioindication and biotesting are employed in the current research on environmental pollution and its impact on the ecological integrity of ecosystems [3].

Natural water and wastewater might be toxic, despite of the fact that it is lightly polluted [4]. Therefore, it is essential to know not only the concentration of polluting substances in water but also the biological and toxic effects caused by them, which may be only assessed applying the set of biotests. The main objective of biotests' application is the effective determination of toxicity level of polluting substances, wastewater and surface water, bottom sediments and soil in order to prevent the release of polluting substances into environment, to increase pollution control, to guarantee the efficiency of wastewater treatment for maintenance of natural water quality [5].

With the employment of test-organisms pollution impact is determined by the reactions of the organisms; i.e. the pollution impact on organisms is assessed. Lepidium sativum L. (a garden cress) classified within the Brassicaceae family is widely applied for biotesting in Canada, the USA and the EU countries (OECD 208, 2003; Phytotoxkit). The impact of tested samples on L. sativum may be evaluated by different test-parameters, for example, a number of germinated seeds, length of roots as well as the biomass of the whole plant or separate parts of it.

The aim of this paper is to determine the sensitivity of a test-organism L. sativum to the toxic impact of different types of samples (liquid or solid: surface water, industrial wastewater, industrial storm water, municipal landfill leachate, lake bottom sediments and sludge from storm water sedimentation tank) from urban environment and chemical substances and to demonstrate the possibilities of application of this plant in both the toxicological investigation and environmental pollution assessment.

\section{OBJECTS AND METHODS}

The substances investigated include: water and bottom sediments of different pollution levels from wastewater canals of Ignalina Nuclear Power Plant (INPP), water and bottom sediments samples from the monitoring stations of Lake Drūkšiai (Ignalina NPP cooler) located closer or further to the Plant, storm wastewater and sludge from the scrap metal processing company (Sweden), leachate water from a landfill (Lithuania), water from reclamation ditches, fuel oil, heavy metals (HM) and their mixtures.

The sludge formed in the storm water sedimentation tank at the scrap metal processing company was 10,20,40,60 and 100 times diluted with distilled water, i.e. until the impact indicator did not statistically differ from the control. In investigation of fuel oil impact on $L$. 
sativum $0.1 \mathrm{~g} / \mathrm{L} ; 1.0 \mathrm{~g} / \mathrm{L} ; 5.0 \mathrm{~g} / \mathrm{L} ; 10.0 \mathrm{~g} / \mathrm{L} ; 25.0 \mathrm{~g} / \mathrm{L} ; 50.0 \mathrm{~g} / \mathrm{L}$ and $100.0 \mathrm{~g} / \mathrm{L}$ concentrations of fuel oil were applied.

In investigation of heavy metals impact (concentrations range from 0.01 to $100 \mathrm{mg} / \mathrm{L}$ ) on $L$. sativum the following chemically pure salts were used: $\mathrm{Cd}\left(\mathrm{NO}_{3}\right)_{2} \cdot 4 \mathrm{H}_{2} \mathrm{O}, \mathrm{CuSO}_{4} \cdot 5 \mathrm{H}_{2} \mathrm{O}$, $\mathrm{K}_{2} \mathrm{Cr}_{2} \mathrm{O}_{7}, \mathrm{MnCl}_{2} \cdot 4 \mathrm{H}_{2} \mathrm{O}, \mathrm{Pb}\left(\mathrm{NO}_{3}\right)_{2}, \mathrm{ZnSO}_{4} \cdot 7 \mathrm{H}_{2} \mathrm{O}$ (Reachim, St. Petersburg, Russia) and $\mathrm{Ni}\left(\mathrm{NO}_{3}\right)_{2}$, (Merck, Darmstadt, Germany).

The composition of heavy metal mixture (HMM) was based on the average data of the annual amounts of HM in wastewater (WW) discharge from Ignalina Nuclear Power Plant into Lake Drūkšiai in 1996. The stock solution of HMM (1000 times higher than WW of INPP) for better solubility of $\mathrm{HM}$ salts was prepared in acidified distilled water using the chemically pure substances such as $\mathrm{Cd}\left(\mathrm{CH}_{3} \mathrm{COO}\right)_{2} \cdot 2 \mathrm{H}_{2} \mathrm{O}, \mathrm{K}_{2} \mathrm{Cr}_{2} \mathrm{O}_{7}, \mathrm{CuSO}_{4} \cdot 5 \mathrm{H}_{2} \mathrm{O}, \mathrm{NiSO}_{4} \cdot 7 \mathrm{H}_{2} \mathrm{O}$, $\mathrm{MnSO}_{4} \cdot 5 \mathrm{H}_{2} \mathrm{O}, \mathrm{Pb}\left(\mathrm{NO}_{3}\right)_{2}$, and $\mathrm{ZnSO}_{4} \cdot 7 \mathrm{H}_{2} \mathrm{O}$ (Reachim, St. Petersburg, Russia). The basic heavy metal mixture solution $\left(\mathrm{HMM}_{100}\right)$ was obtained by diluting stock solution for 1000 times to acquire HM concentrations in WW of INPP (in $\mathrm{mg} / \mathrm{L}$ ): $\mathrm{Pb}-0.0142 ; \mathrm{Cd}-0.000018$; $\mathrm{Cr}-0.00028 ; \mathrm{Ni}-0.00021 ; \mathrm{Cu}-0.0075 ; \mathrm{Mn}-0.0099$, and $\mathrm{Zn}-0.064$, respectively. The following mixture concentrations were applied: $\mathrm{HMM}_{10}, \mathrm{HMM}_{25}, \mathrm{HMM}_{50}, \mathrm{HMM}_{100}$, $\mathrm{HMM}_{250}, \mathrm{HMM}_{500}, \mathrm{HMM}_{2500}$ and $\mathrm{HMM}_{5000}$. The distilled water was used for dilution. The test solutions initially were adjusted to $\mathrm{pH}=5.5 \pm 0.2$ with $0.1 \mathrm{M} \mathrm{HCl}$ or $\mathrm{NaOH}$.

The test with L. sativum was carried out following a modified Magone (1989) method [6]. In brief, $9 \mathrm{ml}$ of distilled water (as a control) or testing sample solution was pipetted onto three layers of filter paper fitted into a 9-cm glass Petri dish. The layers of 5 to $6 \mathrm{~cm}$ of storm water and sludge from the storm water sedimentation tank located at the scrap metal processing company was spread over the Petri dishes. Twenty-five healthy looking and similar size seeds of L. sativum were distributed evenly on the filter paper. The Petri dishes were placed in the dark room at $24 \pm 1^{\circ} \mathrm{C}$ for 48 hours. Afterwards the seed germination and root length of seedlings were measured. Germination of seeds and length of $L$. sativum roots in distilled water were $96 \pm 4 \%$ and from $25.6 \pm 0.7$ to $36.0 \pm 2.8 \mathrm{~mm}$ respectively. The experimental set of each testing scheme involved 3 control dishes and 3 or 5 replicates for each tested sample.

The level of toxic impact on L. sativum was assessed by the modified method of [7]. According to the causing percent of root growth inhibitions of $100-60 \%, 61-40 \%, 41-20 \%$ and lower than $19 \%$ the toxic impact of tested sample solutions or bottom sediments on $L$. sativum was classified as very strong, strong, moderate and weak, respectively. The tested sample was non-toxic if the indicator of root growth of $L$. sativum did not statistically differ from the control indicator, and was extremely toxic if the seed did not germinate at all.

The standard error (SE) was calculated for the statistical evaluation of data. In determining whether the results were statistically different from the control indicators the set of two-intake comparison tests of Statgrahics plus Version 2.1. program when $\mathrm{p}<0,05$ was applied.

The $50 \%$ effective concentration of a toxicant $\left(\mathrm{EC}_{50}\right)$ is one of the most important parameters for toxicity assessment calculated by the regression curve "concentration-response", $\operatorname{lgL}=\mathrm{a}+\mathrm{b} \cdot \operatorname{lgEC}$, when $\mathrm{L}$ stands for the root length in $\%$; $\mathrm{a}$ and $\mathrm{b}$ are constants and $\mathrm{EC}$ is the effective toxicant concentration. $\mathrm{EC}_{50}$ is the toxicant concentration leading to the $50 \%$ reaction of test-organisms when the important alteration of life activity other than mortality is chosen. The $\mathrm{EC}_{50}$ of 24,48 or 96 hours or longer is subject to the duration of impact. In case of $L$. sativum a 48 hour $\mathrm{EC}_{50}\left(48 \mathrm{~h}-\mathrm{EC}_{50}\right)$ was applied. 


\section{RESULTS AND DISCUSSION}

The investigation of Ignalina NPP wastewater impact on L. sativum (from 1996 to 2000) indicated that in most cases the number of germinated seeds did not differentiate $(p<0,05)$ or almost did not differentiate from the control indicators. However, the growth rates of $L$. sativum roots due to the impact of the analysed wastewater ranged from $54 \%$ to $95 \%$ (Fig. 1).

From the total amount of tested wastewater from Ignalina NPP during 1996-2000 only the results of year 1998 were positive. In most cases wastewater from WWTP was the most toxic; the growth rates of roots there ranged from $54 \%$ to $65 \%$. The water of Lake Drūkšiai was also toxic and made impact on the growth of $L$. sativum roots since the growth rates (except in 1998) ranged from $55 \%$ to $84 \%$ (see Figure 1). The rate of toxicity of Lake Drükšiai water was dependant on the pollution level of Ignalina NPP wastewater, distance from the pollution resource, wind direction, water flow and mixing of water masses.

The toxicity investigation of both Lake Drūkšiai surface water and bottom sediments as the location of concentration of various toxic substances was executed in order to assess the ecotoxical state of the lake. The impact of bottom sediments samples collected from 132 locations of the Lake Drūkšiai on $L$. sativum was assessed for the evaluation of ecological situation (see Figure 2).

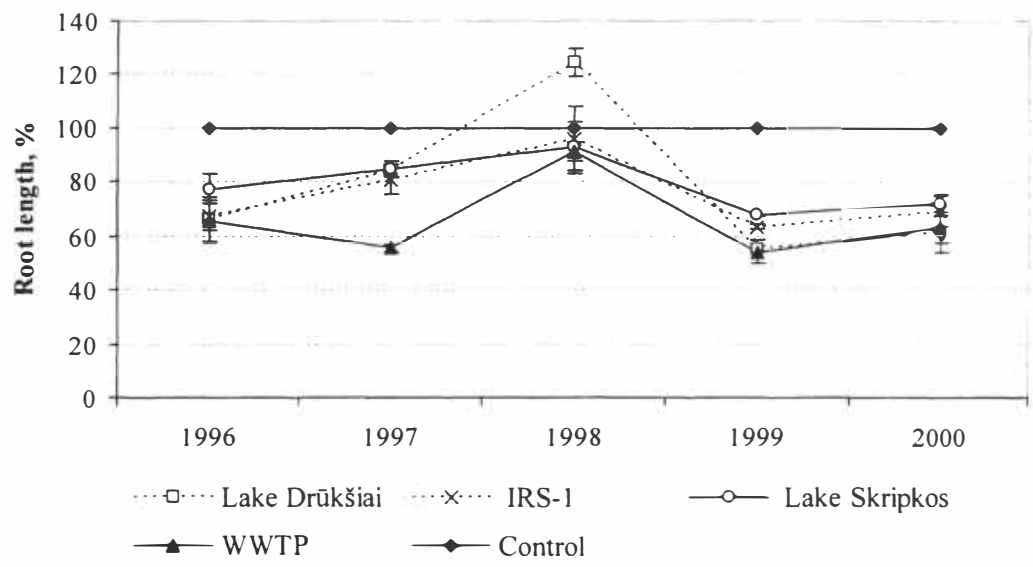

Figure 1. Toxic effect of Ignalina NPP wastewater and water of Lake Drükšiai, the cooler of Ignalina NPP, on L. sativum;

IRS-1 - industrial wastewater and storm water run-off canal; WWTP - wastewater treatment plant; Lake Skripkos - the lake which is on the route of the wastewater from WWTP to Lake Drükšiai.

The results indicated that only few samples of tested bottom sediments were non-toxic (see Fig. 2). A very strong toxic impact was indicated by 13 samples of bottom sediments collected from eutrophicated shoal zones of the lake where the municipal wastewater was disposed as well as the littoral areas of the lake. The results of samples of bottom sediments discharged from the main, very deep and windy area of the lake with the industrial and storm water as well as heated wastewater disposed there indicated a moderate toxic impact. 


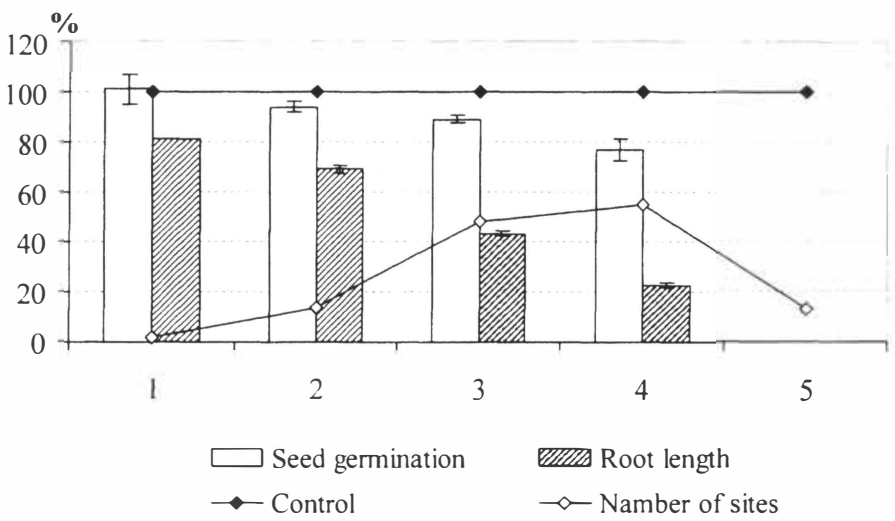

Figure 2. Toxic effect of Lake Drūkšiai bottom sediments on L. sativum

1. Non toxic or weak toxic effect; 2. Medium toxic effect; 3. Strong toxic effect; 4. Very strong toxic effect; 5. Extremely toxic effect.

It is quite possible that the toxic substances disposed into Lake Drūkšiai together with the wastewater of Ingalina NPP were rapidly drifted to the littoral areas of the lake due to the intensive mixing and strong water currents produced in the intake and heated water canals. The results of the highest toxicity of Lake Drūkšiai bottom sediments in most cases coincided with the borders of a area exposed to the highest level of geochemical contamination identified by K. Jokšas and others in 1997 [8]. The data obtained identified bottom sediments as more informative type of sample for the assessment of watersheds pollution than water.

The research results of toxic impact of storm water and sludge from the scrap metal processing plant on L. sativum indicated that the storm water was slightly toxic and sludge was very toxic (see Fig. 3). After sludge had been 10 and 20 times diluted with distilled water it became of moderate toxicity, meanwhile 40 and 60 times diluted it was slightly toxic. The impact of sludge diluted for 100 times to this plant was not statistically different from the control indicators (see Figure 3). Depending on the sludge dilution the growth rate of $L$. sativum roots ranged from 56 to $99 \%$, and the germination rate of seeds from 89 to $96 \%$ (see Figure 3).

The results of toxicity investigation of leachate water from a municipal landfill (Lithuania) rich with industrial waste, water from reclamation ditches where leachate was disposed and pond water where water from ditches was disposed to L. sativum indicated that all investigated watersheds were toxic; however, the level of toxicity differed (see Figure 4).

Leachate water from the landfill and reclamation ditch (No.2) closest to the leachate tank was very toxic since the germination of seeds equalled to zero. The toxicity of water from reclamation ditches No. 3 and No. 4 was also very strong and strong respectively, although they were situated further from the leachate tank. In comparison with the control indicators the germination rates were $20 \%$ and $50 \%$ respectively, and the root growth was $36 \%$ and $54 \%$ respectively (see Figure 4). 


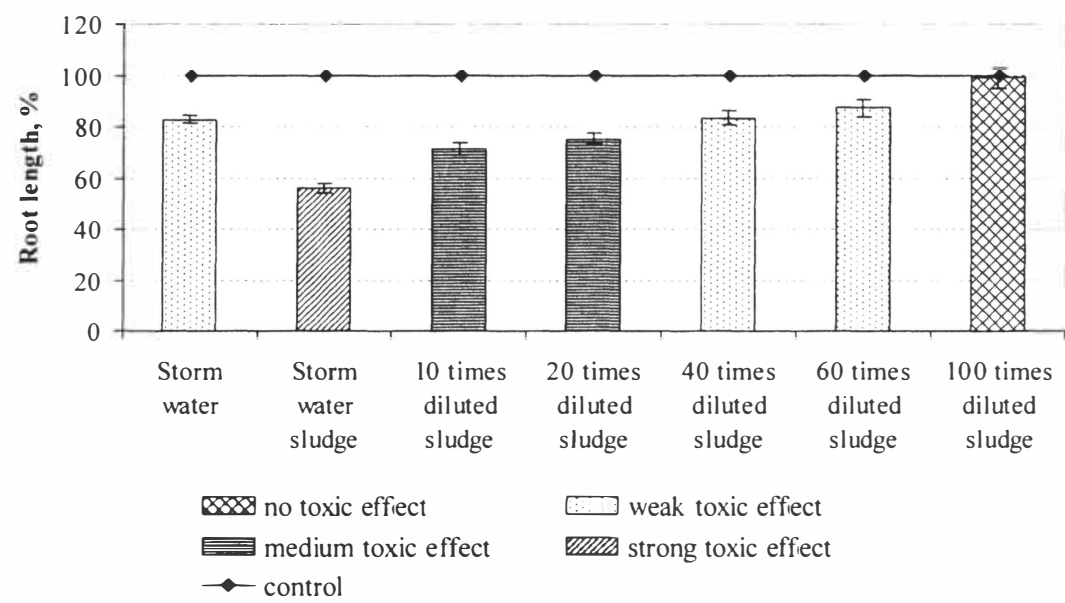

Figure 3. Toxic effect of industrial storm water and sludge(from storm water sedimentation tank) formed at metal scrap processing industry (Sweden) area on L. sativum

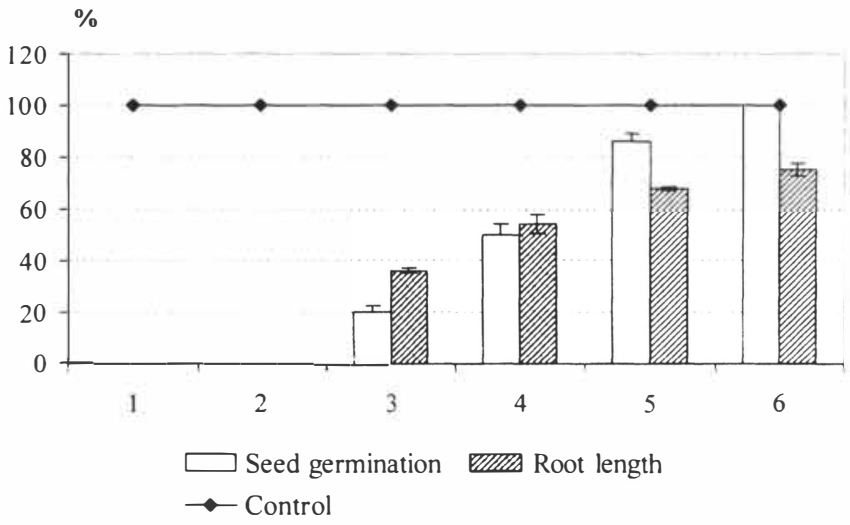

Figure 4. Toxic effect of leachate from municipal landfill rich with industrial waste (Lithuania) on L. sativum (samples were taken from leachate tank, reclamation ditches, pond and out-flow ditch)

1 - leachate tank; 2-4 - reclamation ditches to which leachate is discharged; 5 - pond to which water from reclamation ditches is collected; 6 - rivulet running from the pond.

Water from reclamation ditch (No.4) floated into the pond (No.5), which was of moderate toxicity, since $86 \%$ of $L$. sativum seeds germinated in this water and the length of roots reached $68 \%$ (see Figure 4). $100 \%$ of seeds germinated from the water of rivulet (No. 6) running from the pond; however, the length of roots did not exceed $70 \%$ in comparison with the control indicator (see Figure 4). The water was also of moderate toxicity. 
The investigation of toxic impact of fuel oil, heavy metals and their mixture on germination of seeds and root growth of $L$. sativum was carried out in order to evaluate the sensitivity of $L$. sativum to separate toxicants included into the composition of wastewater produced by industrial plants and landfill leachate. Also the $50 \%$ effiective concentration of these toxicants $\left(48 \mathrm{~h}-\mathrm{EC}_{50}\right)$ was applied allowing the comparison of the impact of toxicants on different organisms.

The results of the investigation indicated that the indicators of L. sativum seed germination in all tested oil concentrations did not differ from the control indicators. Also the results showed that the growth rates of roots in the minimal oil concentration $(0.1 \mathrm{~g} / \mathrm{L})$ did not statistically differ from the control indicators. With the oil concentration of $1 \mathrm{~g} / \mathrm{L}$ the length of roots was $84.2 \%$; meanwhile with the oil concentration of $5 \mathrm{~g} / \mathrm{l}$ the length reached $54.4 \%$ (see Figure 5).

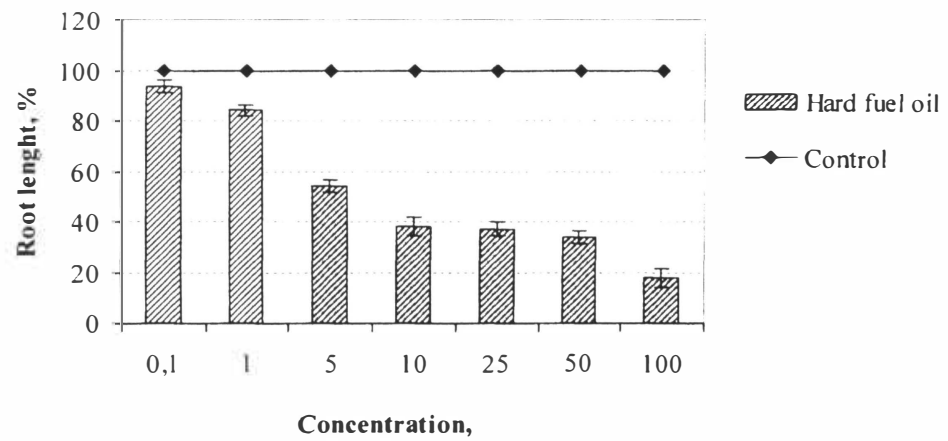

Figure 5. Toxic effect of hard fuel oil on L. sativum

With the oil concentration of $10-100 \mathrm{~g} / \mathrm{l}$ the growth of $L$. sativum roots decreased from 38.2 to $17.9 \%$ respectively (see Figure 5). It was calculated that the $50 \%$ effective fuel oil concentration (48-h $\mathrm{EC}_{50}$ ) according to the growth rates of $L$. sativum roots was $8.7 \mathrm{~g} / \mathrm{L}$. Meanwhile, 14 day-EC ${ }_{50}$ for Spirodela polyrrhiza (L.) classified within the Lemnaceae family was $18.7 \mathrm{~g} / \mathrm{L}$; $96 \mathrm{~h}-\mathrm{EC}_{50}$ of fuel oil for the adults' rainbow trout (Oncorhynchus mykyss Wallbaum.) made $3.0 \mathrm{~g} / \mathrm{L} \mathrm{[9].}$

Investigation of the toxicity of heavy metals ( $\mathrm{Cd}, \mathrm{Cu}, \mathrm{Cr}(\mathrm{VI}), \mathrm{Mn}(\mathrm{II}), \mathrm{Pb}$, and $\mathrm{Zn})$ on $L$. sativum showed that seed germination in the tested HM concentrations differed insignificantly from the control indicator, except, with the highest concentration $(10 \mathrm{mg} / \mathrm{L})$ of $\mathrm{Cu}$, which decreased seed germination by $20 \%$. The toxicity of $\mathrm{HM}$ was assessed using the $48-\mathrm{EC}_{50}$ values (i.e. metal concentration that induce $50 \%$ root growth inhibition of $L$. sativum as percentage of control indicator, in 48-h experiments). The comparison of the 48 -EC $\mathrm{E}_{50}$ values of all tested HM showed that $\mathrm{Cr}(1.8 \mathrm{mg} / \mathrm{L})$ was most toxic to L. sativum and $\mathrm{Mn}(\mathrm{II})$ was the least toxic (see Figure 6). It was estimated that the toxicity of the test metals decreased in the following order $\mathrm{Cr} \gg \mathrm{Cu}>\mathrm{Cd}>\mathrm{Ni}=\mathrm{Pb}>\mathrm{Zn}>\mathrm{Mn}$ (Figure 6). Very few literature data was available for comparison with our results. Wang (1986) found that the order of toxicity for root growth of lettuce and millet was the following: $\mathrm{Ni}>\mathrm{Cd}>\mathrm{Cu}>\mathrm{Cr}(\mathrm{VI})>\mathrm{Zn}>\mathrm{Mn}$ and $\mathrm{Cu}, \mathrm{Ni}>\mathrm{Cd}>\mathrm{Cr}(\mathrm{Vl})>\mathrm{Zn}>\mathrm{Mn}$, respectively [10]. In 1998 Fargasova presented the following order of metals toxicity for root elongation of Sinapis alba: $\mathrm{Cu}^{2+}>\mathrm{MoO}_{4}{ }^{2-}>\mathrm{Ni}^{2+}>$ $\mathrm{Mn}^{2+}>\mathrm{VO}_{4}{ }^{3-}[11]$. 

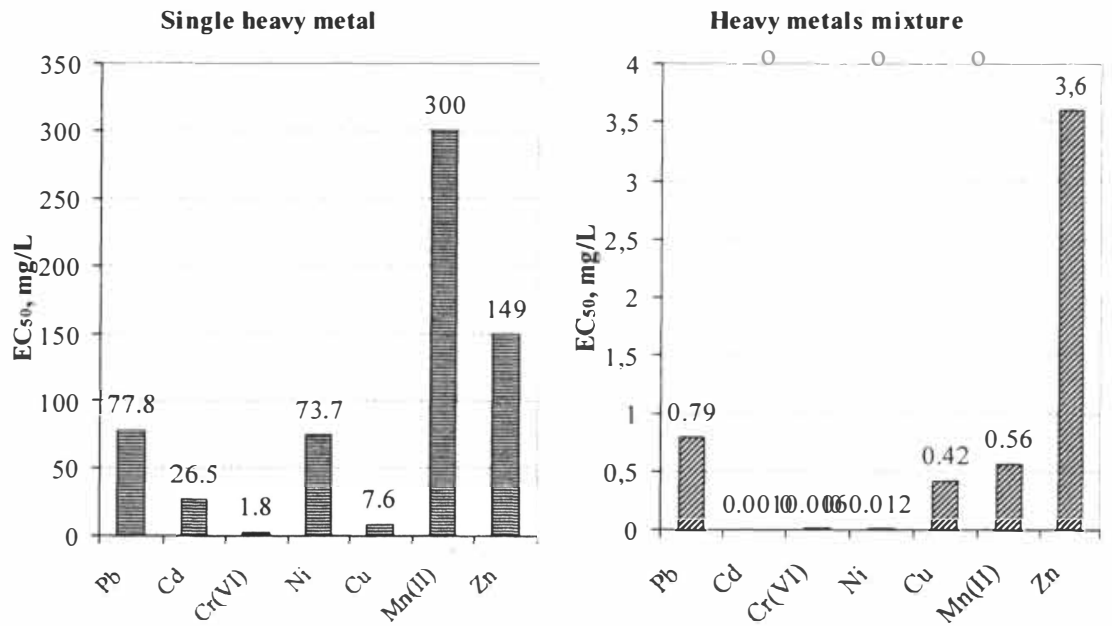

Figure 6. 50\% effective concentrations $\left(48 \mathrm{~h}-E C_{50}, \mathrm{mg} / \mathrm{L}\right)$ of single heavy metals and their in the heavy metals mixture for L. sativum

The investigation of the toxic impact of heavy metal mixture on $L$. sativum identified that concentrations of $\mathrm{HMM}_{10}, \mathrm{HMM}_{25}, \mathrm{HMM}_{50}, \mathrm{HMM}_{100}, \mathrm{HMM}_{250}$ and $\mathrm{HMM}_{500}$ had no impact on the germination of seeds and root growth of this plant $(\mathrm{p}<0.05)$. The indicators of seed germination of $\mathrm{M}_{2500}$ and $\mathrm{HMM}_{5000}$ concentrations did not differ form the control $(\mathrm{p}<0.05)$, however, the root growth rate decreased to 78.2 and $56.3 \%$ respectively. The calculation of $48 \mathrm{~h}-\mathrm{EC}_{50}$ values of the HM mixture for tested plant showed that the root length decreased by $50 \%$ when the basic concentration $\left(\mathrm{HMM}_{100}\right)$ of $\mathrm{HM}$ mixture was increased to 56.2 times. It was established that the concentrations of $\mathrm{HM}$ in the mixture that caused the analogous toxic effect $\left(48 \mathrm{~h}-\mathrm{EC}_{50}\right)$ on $L$. sativum were from several to hundred times lower than the concentration of single metals that caused the same effiect. For example, $48 \mathrm{~h}$-EC50 values of single $\mathrm{Cu}$ and $\mathrm{Ni}$ for $L$ sativum were 7.6 and $73.7 \mathrm{mg} / \mathrm{L}$, while the concentrations of these metals in the mixture was only 0.4 and $0.012 \mathrm{mg} / \mathrm{L}$, respectively (see Figure 6). It shows that the toxicity of HMM can be stipulated by the interaction within the mixture.

The results of conducted investigation have proved that $L$. sativum is a sufficiently universal, cheap and sensitive biotest for determination of toxicity of various liquid or solid samples, for example: storm water, bottom sediments from surface water, soil, wastewater from industrial sites, landfill leachate and included chemical substances. Therefore, it can be successfully applied in the environmental pollution assessment.

\section{REFERENCES}

[1] Wundram, M, Selmar D, Bahadir, M., 1997. Representative evaluation of phytotoxicity - reliability and peculiarities. Angew Bot 71, 139-143.

[2] Marčiulioniené, D, Montvydienè, D, Kazlauskiene, N, Svecevičius, G., 2002. Comparative analysis of the sensitivity of test-organisms of different phylogenetic level 
and live stages to heavy metals. Environmental and Chemical Physics (Vilnius, Lithuania) 24(2), 73-78.

[3] Blinova, I. 2004., Use the freshwater algae and duckweeds for phytoxicity testing. Environmental Toxicology 19(4):425-428.

[4] Montvydienè, D, Lakačauskienė, R, Marčiulionienè, D., 2000. Assessment of toxicity of heavy metal model and natural mixtures for higher plants. Botanica Lithuanica (Vilnius, Lithuania) 6(3), 281-297.

[5] Vosylienè, M.-Z., Marčiulionienè, D., Kazlauskienè, N., Montvydienè, D., Svecevičius, G., 2003. The use of biological test complex for the water toxicity assessment. Lithuanian Society of Metaloecology. Vilnius. p. 16.

[6] Magone, I., 1989. Bioindication of phytotoxicity of transport emission. In: Kachalova O. L., editor. Bioindication of toxicity of transport emissions in the impact of highway emissions on natural environment. Riga, Latvia: Zinatne. p 108-116.

[7] Wang, W. 1992., Use of plants for the assessment of environmental contaminants. Reviews of Environmental Contamination and Toxicology 126, 88-127.

[8] Jokšas, et al.,1997. The peculiarity of the transformation and accumulation of sediments and chemical substances in the Druksiai lake. Lithuanian research programme "Nuclear energy and environment" the array of research reports, 1993-1997 I part. Vilnius, 119225.

[9] Kazlauskienė, N., Svecevičius, G., Vosylienė, M.-Z., Marčiulionienė, D., Montvydienè, D. 2004. Comparative study on sensitivity of higher plants and fish to heavy fuel oil. Environmental Toxicology 19(4), 449-451.

[10] Wang, W., 1986. Root elongation method for toxicity testing of organic and inorganic pollutants. Environmental Contamination and Toxicology 6, 409-414.

[11] Fargasova, A., 1998. Root growth inhibition, photosynthetic pigments production, and metal accumultation in Sinapis alba as the parameters for trace metals effect determination. Bull Environ Contam Toxicol 61, 762-769. 